\title{
Long-term mangrove forest development in Sri Lanka: early predictions evaluated against outcomes using VHR remote sensing and VHR ground-truth data
}

\author{
Behara Satyanarayana ${ }^{1,2,3}$, Nico Koedam ${ }^{2}$, Kriki De Smet ${ }^{2}$, Diana Di Nitto ${ }^{1,2}$,

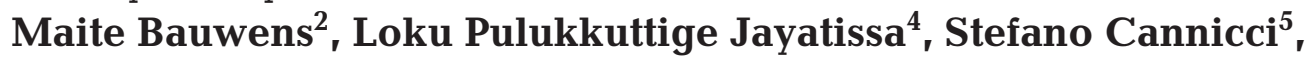 \\ Farid Dahdouh-Guebas ${ }^{1,2, *}$

\footnotetext{
${ }^{1}$ Laboratory of Systems Ecology and Resource Management, Département de Biologie des Organismes, Faculté des Sciences, Université Libre de Bruxelles-ULB, Avenue Franklin D. Roosevelt 50, 1050 Brussels, Belgium

${ }^{2}$ Laboratory of Plant Biology and Nature Management, Mangrove Management Group, Vrije Universiteit Brussel-VUB, Pleinlaan 2, 1050 Brussels, Belgium

${ }^{3}$ Institute of Oceanography, University Malaysia Terengganu (UMT), 21030 Kuala Terengganu, Malaysia

${ }^{4}$ Department of Botany, University of Ruhuna, Matara, Sri Lanka

${ }^{5}$ Dipartimento di Biologia Evoluzionistica, Università degli Studi di Firenze, via Romana 17, 50125 Firenze, Italy
}

\begin{abstract}
Whereas anthropogenic impacts on the mangroves are often directly visible, some indirect impacts like biodiversity change are witnessed only over a period of time and therefore require medium to long-term monitoring. This study focuses on testing the predictions made $10 \mathrm{yr}$ ago concerning the evolution of a mangrove forest in Galle-Unawatuna, Sri Lanka. The very high resolution (VHR) ground inventory revealed that the adult mangrove species composition is dominated by Rhizophora apiculata, Excoecaria agallocha, Bruguiera gymnorrhiza and B. sexangula, with a total density of 216 to 267 stems $0.1 \mathrm{ha}^{-1}$ and a basal area of 1.19 to $1.44 \mathrm{~m}^{2} 0.1 \mathrm{ha}^{-1}$. However, both young and juvenile vegetation in most sectors were dominated solely by $B$. gymnorrhiza (128 to 869 stems and 356 to 1482 propagules 0.1 ha $^{-1}$ ). The recent decadal changes between 1994 and 2004 observed through IKONOS imagery and ground truthing confirmed many of the predictions and showed dynamic shifts in young/adult vegetation of B. gymnorrhiza. Although dominance of $R$. apiculata and E. agallocha has been seen to alternate over decades (1956 to 2004), the emerging growth of B. gymnorrhiza might cause yet another transition of this mangrove area into a Bruguiera-dominated forest in the near future, resulting in the conclusion that the 'moving mosaic' pattern of mangrove species distribution at Galle-Unawatuna still persists. We maintain that this mangrove forest is probably one of the most dynamic in the world in terms of species turnover. To our knowledge, the present study represents one of the few long-term field-based monitoring research projects on mangroves using VHR remote sensing and VHR fieldwork at decadal intervals, and is probably the only study testing forest development predictions made in the past.
\end{abstract}

KEY WORDS: Decadal changes · Galle-Unawatuna · Mangrove distribution - Remote sensing · Species-environment relationship · Sri Lanka · Forecasting Resale or republication not permitted without written consent of the publisher

\section{INTRODUCTION}

Tropical mangrove forests are among the most productive ecosystems in the world (Ellison 2008, Nagelkerken et al. 2008), providing direct and indi- rect services for the local fishing communities (Mumby et al. 2004, Dahdouh-Guebas et al. 2005a, Walters et al. 2008). They are also important regulators of coastal ecosystem processes (DahdouhGuebas et al. 2007, Ren et al. 2009), and assist in 
buffering the consequences of sea-level rise and ocean surges (Dahdouh-Guebas \& Koedam 2006a, Quartel et al. 2007, Alongi 2008, Gilman et al. 2008, Sanford 2009, Feagin et al. 2010). They are considered to be among the most carbon-rich forests in the tropics (Donato et al. 2011).

However, several anthropogenic activities, particularly aimed at short-term profit at the expense of long-term productivity, pose a threat to mangroves ubiquitously (Valiela et al. 2001). They have been found to be declining much faster than inland tropical rainforests (Duke et al. 2007), but with little public notice or relatively few organized reforestation programs (Kairo et al. 2001, Bosire et al. 2008). Recent works (e.g. Kairo et al. 2002, Jayatissa et al. 2002) have also indicated that decline in the biological diversity and economic value of mangroves is due to overexploitation of certain important species, which in turn alters the floristic composition or vegetation structure.

In view of logistic as well as practical difficulties involved in qualitative and quantitative assessment of mangroves through field surveys, remote sensing and global distribution data are becoming indispensable (Kovacs et al. 2004, Giri et al. 2007, 2008, 2011, Massó i Alemán et al. 2010). Moreover, very high resolution (VHR) special data acquired from modern satellite sensors is extremely useful for distinguishing mangrove species and/or species assemblages within the forest (Dahdouh-Guebas et al. 2005b, Proisy et al. 2007, Neukermans et al. 2008, Satyanarayana et al. 2011).

Sri Lankan mangroves have attracted attention for several decades (see Dahdouh-Guebas et al. 2000 for details), with recent works utilizing remote sensing (Verheyden et al. 2002, Dahdouh-Guebas et al. $2005 b, 2006)$. The present study is primarily based on the work of Dahdouh-Guebas et al. (2000), who studied the Galle-Unawatuna mangrove evolution between 1956 and 1994. The major structural changes which occurred in the Galle-Unawatuna mangroves at decadal intervals (cf. Dahdouh-Guebas et al. 2000) make a continuation of change detection highly relevant. In this context, Dahdouh-Guebas et al. (2000) used forestry parameters (e.g. density) of the young and juvenile vegetation to formulate possible structural changes. They forecasted (1) the transition of an Excoecaria agallocha L. forest into one dominated by Bruguiera gymnorrhiza (L.) Lamk., or at least their co-dominance in Sectors 1 and 2 (sectors as outlined in Fig. 1), (2) the persistence of adult and juvenile Rhizophora apiculata Bl. in Sector 3, and (3) the possibility of mangrove vegetation becoming domi- nated by Bruguiera species in the Galle-Unawatuna area.

Since both natural and anthropogenic influences can alter the structure and extent of mangrove cover, these forests must be assessed periodically for areal estimations and forest loss/expansion (Souza Filho et al. 2006, Berger et al. 2008). With the availability of suitable remote sensing technologies to explain such changes in mangrove forests, the objective of the present study was to test the above predictions made 10 yr ago.

\section{MATERIALS AND METHODS}

\section{Study area}

The sheltered mangroves at Galle-Unawatuna cover nearly $1.5 \mathrm{~km}^{2}\left(06^{\circ} 01^{\prime} \mathrm{N}, 80^{\circ} 14^{\prime} \mathrm{E}\right)$ and are situated $600 \mathrm{~m}$ from the Indian Ocean at the southern end of Sri Lanka (Fig. 1). Jayatissa et al. (2002) reported 10 mangrove species and 13 mangroveassociated species for southern Sri Lanka with 'common' to 'very common' frequency, based on total abundance. Among others, Rhizophora apiculata, Excoecaria agallocha, Bruguiera gymnorrhiza, and B. sexangula (Lour) Poir., along with mangrove-associates such as Acanthus ilicifolius L., Acrostichum aureum L., Clerodendron inerme (L.) Gaertn., and Dolichandrone spathacea (L.F.) K. Schum. are abundant in Galle-Unawatuna. Although tidal water enters into this mangrove area through the Thalpe Ela and Galu Ganga Rivers, there is no daily tidal inundation due to dam and road (access to dam) construction (1985) in the vicinity. However, even on the seaward side of the dam, the tidal influence is extremely small (a few decimeters). Some major vegetation shifts along with changes in the physicochemical conditions of the water have been reported after the above-mentioned physical infrastructure developments (Dahdouh-Guebas et al. 2000, Mulder 2005). Nevertheless, the monthly water level observations between 1985 and 1999 have also revealed that there have only been 2 flooding months $(1.1 \%$ of the months) since the dam was built (DahdouhGuebas et al. 2011). The dust from a cement factory (Ruhunu Cement Company) was also observed on some mangrove patches in the same area. The climate is generally hot and humid with the precipitation characterized by wide seasonal and regional variations. The monsoon season in the southwest of Sri Lanka lasts from May to November, with intense rainfall during this time period. 


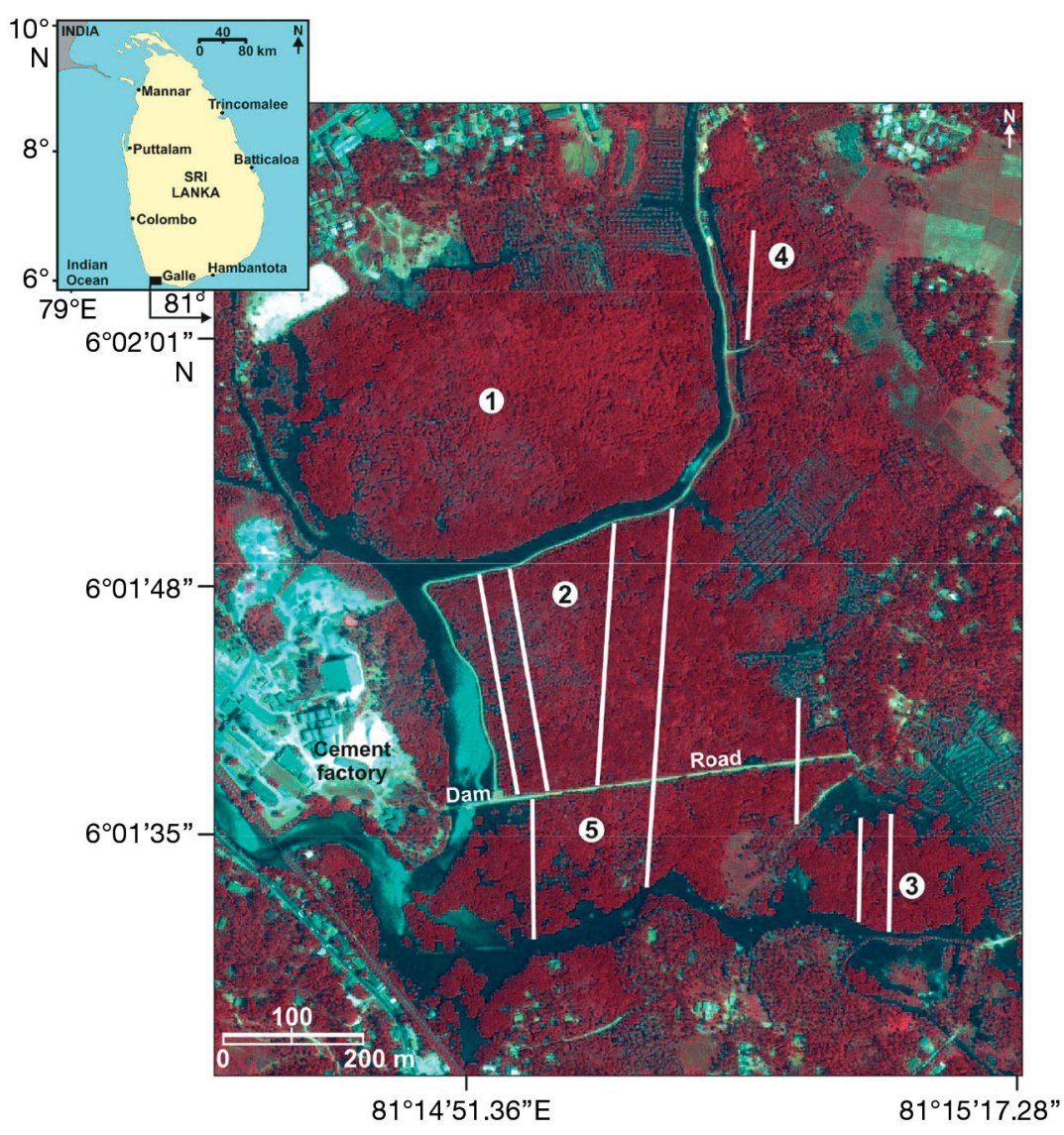

Fig. 1. Pan-sharpened IKONOS satellite image showing mangroves at GalleUnawatuna on the Sri Lankan south coast. The study area was divided into 5 sectors (numbered in white circles) and fieldwork was conducted along transects (white lines) applying the point-centred quarter method

\section{Ground-truth data collection}

Based on the degree and direction of vegetation change, Dahdouh-Guebas et al. (2000) divided the Galle-Unawatuna mangrove area into 4 sectors as outlined in Fig. 1. However, we have now included one more area close to the dam in the south as Sector 5 for better vegetation structure analysis and interpretation. In each sector, the sampling technique (i.e. the point-centred quarter method, PCQM; Cintron \& Schaeffer Novelli 1984) was the same as that used by Dahdouh-Guebas et al. (2000) for estimating various forest structural parameters, such as density (stems $\left.0.1 \mathrm{ha}^{-1}\right)$, basal area $\left(\mathrm{m}^{2} 0.1 \mathrm{ha}^{-1}\right)$, relative density $(\%)$, relative dominance $(\%)$, relative frequency $(\%)$, and Importance Value (IV) (sum of relative density, dominance and frequency). PCQM is efficient for covering large areas and sampling diverse vegetation with minimal understory damage (Dahdouh-Guebas \& Koedam 2006b). The sampling was carried out along transects (Fig. 1), at sampling points established at $10 \mathrm{~m}$ intervals. In total, our study included 201 sampling points, and incorporated an additional 171 sampling points from $10 \mathrm{yr}$ ago (Dahdouh-Guebas et al. 2000). Each sampling point was subdivided into 4 quadrants (i.e. a quarter of the plane in which the sampling point was located, with the sampling point in the center of the 4 quarters). In each quadrant, the distance from the sampling point to the nearest tree, the tree diameter at a height of $130 \mathrm{~cm}$ measured along the stem $\left(D_{130}\right.$, formerly referred to as the diameter at breast height, $\mathrm{DBH})$, and the height of the sampled tree were measured. Taking into account the suggestions offered by Dahdouh-Guebas \& Koedam (2006b), both distance and $\mathrm{D}_{130}$ were measured with the help of measuring tape $(5 \mathrm{~mm}$ accuracy), and the tree height was measured using a hypsometer (Suunto $\left.^{\mathrm{TM}}\right)$. The coconut palm Cocos nucifera L. was also recorded if present in any quadrat along the PCQM transect line. The complexity index (CI) of mangroves in each sector was computed following Holdridge et al. (1971) using the formula: (No. of species) $\times($ Stand density $) \times($ Stand basal area $) \times($ Mean tree height) $\times 10^{-3}$.

Eleven transects encompassing 201 sampling points were spread across the whole forest (Sector 2: 5 transects; Sector 3: 2 transects; Sector 4: 1 transect; Sector 5: 3 transects) (July to August 2004), while Sector 1 was unexplored due to reported hostility from illegal arrack (local liquor) distillers. However, several (random) ground checks were made to record the mangrove species composition and distribution in various pockets of Sector 1. Moreover, the results already available from this sector (see Dahdouh-Guebas et al. 2000) were considered for present study/data interpretation as far as canopy vegetation was concerned. In each transect, both adult and young trees were estimated separately (divisions based on Kairo et al. 2002). The mangrove juveniles (fallen propagules and saplings with 3 leaf pairs or less) were counted within $1 \times 1 \mathrm{~m}^{2}$ plots at each sampling point. The definitions for juvenile, young and adult trees correspond to particular stages in distribution and survival. Juveniles represent a possibility 
for a species to reach a particular location through simple fall and/or hydrochory (cf. Di Nitto et al. 2008), young trees represent survival from propagule predation (Bosire et al. 2005, Cannicci et al. 2008), and adult trees represent survival from unfavorable environmental conditions (Cannicci et al. 2008, Krauss et al. 2008). The taxonomic identification of mangroves is based on the nomenclature suggested by Tomlinson (1986). A global positioning system (Garmin GPS III) was used for navigation and ground checks during the fieldwork.

Environmental parameters such as temperature $\left({ }^{\circ} \mathrm{C}\right)$, light intensity (lux), relative humidity $(\%)$, salinity (\%o), and land/water ratio (\% land) were measured at each sampling point along the transects. The light intensity was measured using a Luxtron lux meter (LX150, Fisher Scientific), while both temperature and relative humidity were recorded with the help of a digital Max-Min Thermometer-Hygrometer (Fisher Scientific). A hand refractometer (Atago, S/Mill-E) was used for measuring salinity (accuracy: $\pm 1 \%$ ). For the land to water ratio, the area occupied by land as opposed to water was estimated visually in the $5 \times$ $5 \mathrm{~m}^{2}$ plot closest to the sampling point in each quadrant and was expressed as percentage land cover. This level hardly changed during the fieldwork, but is known to change after heavy rainfall or changes in the level of the river (see Dahdouh-Guebas et al. 2011).

\section{VHR remote sensing data}

Mangrove vegetation maps based on the 1956, 1974 and 1994 aerial photographs of GalleUnawatuna were adopted from Dahdouh-Guebas et al. (2000), and reproduced in color for clear change detection (ArcGIS v.9.3). The recent decadal changes between 1994 and 2004 in the forest were analyzed using the pan-sharpened multispectral IKONOS VHR satellite imagery (spatial resolution: $1 \mathrm{~m}$ ) acquired on 20 February 2004. The geometric correction of this satellite image was carried out using 29 well spread ground control points (GCPs) covering clearly recognizable features, such as the cement factory, the dam, and road junctions, recorded with our GPS in the field. We adapted the procedures for image analysis from Neukermans et al. (2008) as described below. After geometric correction (root mean square [RMS] error: 0.682), the exclusive mangrove area of Galle-Unawatuna was extracted by masking the other features for better classification accuracy (using ERDAS imagine v.8.5).
Within the mangrove forest, various vegetation classes were delineated through training sites (based on experienced field knowledge), and supervised classification applying the maximum likelihood decision rule (Wang et al. 2004a) was performed. However, in some cases there were 2 classes that represented the same dominant species (e.g. Bruguiera and Rhizophora) due to prevailing mixed vegetation patches. The accuracy was checked by means of an error matrix (e.g. Congalton 1991), comparing the results of the classified image with ground-truth (PCQM) data, which has been effective in previous combinatory investigations (Neukermans et al. 2008). Moreover, various vegetation types, such as pure stands as well as mixed combinations of Bruguiera, Excoecaria and/or Rhizophora spp., were digitized on-screen and converted into vector- and grid-based maps for comparing individual species' groupings between 2004 and 1994. The area statistics for each mangrove class (in percentage cover) were estimated based on Neukermans et al. (2008) using the formula: (Histogram value $\times$ Pixel size $\left.\left(\mathrm{m}^{2}\right)\right) / 10^{6}$.

\section{Vegetation structure analysis}

Firstly, a land-use and cover map of GalleUnawatuna for 2004 was produced and statistics for each dominant mangrove species were derived (ArcGIS v.9.3). Secondly, the species' distributional maps of 1994 and 2004 were compared both qualitatively and quantitatively. Finally, the speciesenvironment relationship was established through canonical correspondence analysis (CCA) (CANOCO for Windows v.4.5) (ter Braak \& Smilauer 2002).

\section{RESULTS}

\section{Current mangrove distribution}

Based on the adult tree structural attributes, Sectors 2, 3, 4 and 5 were dominated by Excoecaria agallocha, Rhizophora apiculata, Bruguiera gymnorrhiza, and $B$. sexangula, respectively (Table 1 ). However, the young vegetation layer was largely dominated by Bruguiera spp. irrespective of the sector and of the adult tree dominance, except for Sector 5 where $R$. apiculata was dominant (Table 2). In terms of forest development, the mangroves were found to be structurally complex (9.9 to 10.6) (Table 1), except in Sector 2 (5.7). 


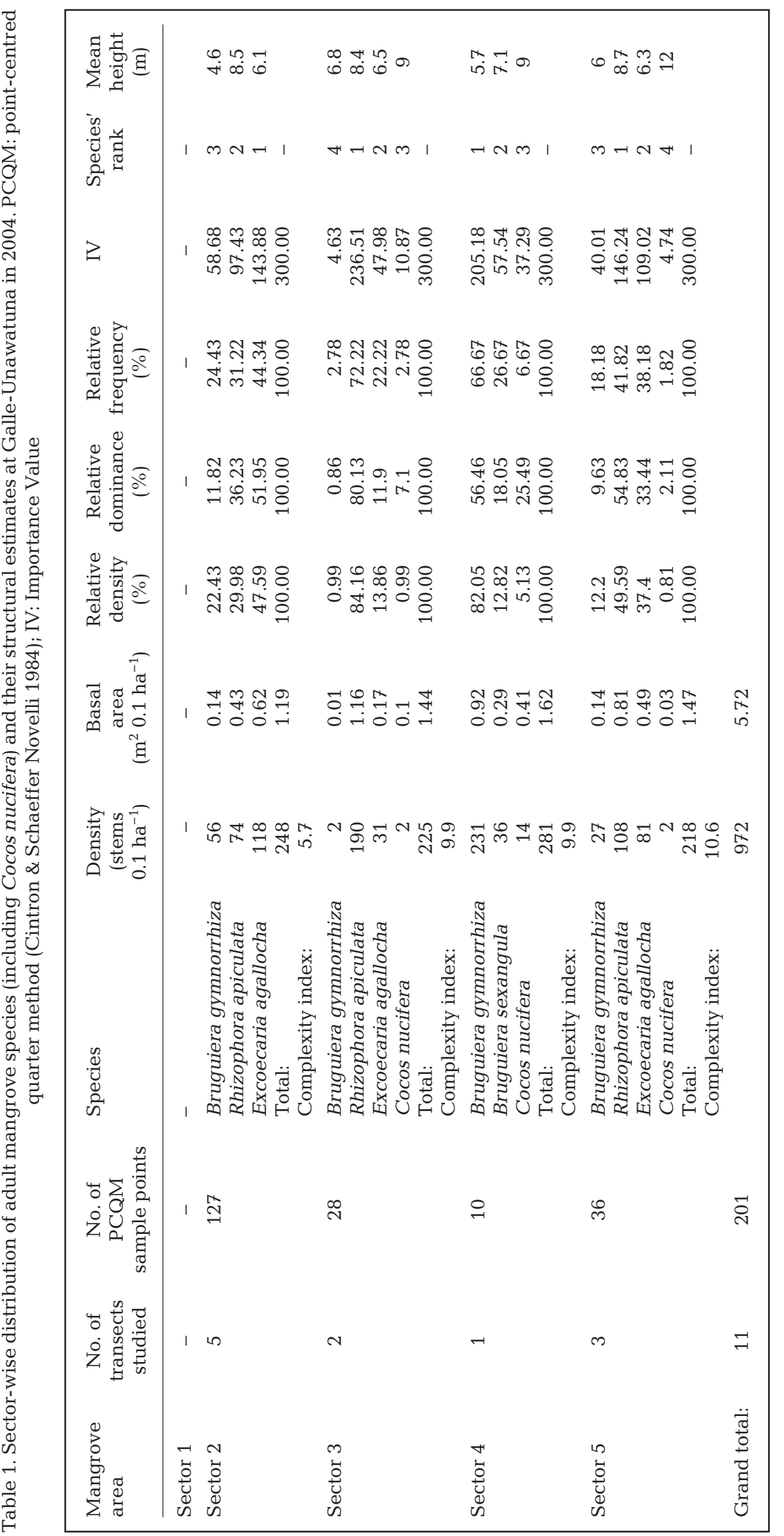

\section{Mangrove mapping}

The land-use and cover classification of Galle-Unawatuna mangroves based on IKONOS satellite imagery confirmed the prevalence of Excoecaria agallocha and Bruguiera gymnorrhiza in the landward Sectors 1 and 2 (Fig. 2), whereas Rhizophora apiculata retained dominance on the river banks. $R$. apiculata and Bruguiera spp. were abundant in Sectors 3 and 4, respectively. Sector 5 had mixed vegetation including $B$. gymnorrhiza, E. agallocha and $R$. apiculata. Overall, $R$. apiculata was the adult dominant species occupying $42 \%$ of the total forest followed by E. agallocha $(18 \%)$ and B. gymnorrhiza $(9 \%)$. The accuracy of the classification was $62.5 \%$, and the tau coefficient indicated $52 \%$ correct allocation of the pixels (Table 3 ).

\section{Mangrove decadal changes}

The major changes between 1994 and 2004 were transitions within the mixed mangrove assemblages (Fig. 3, Table 4). New classes delineated on the 2004 satellite imagery included a pure stand of Bruguiera gymnorrhiza (Sectors 1 and 4), a combination of Rhizophora apiculata and B. gymnorrhiza (Sector 2), and a combination of Excoecaria agallocha, $R$. apiculata and B. gymnorrhiza (Sectors 1 and 2). The images also indicated that the combination of Bruguiera spp. and E. agallocha in Sector 1 reported $10 \mathrm{yr}$ ago is now dominated by B. gymnorrhiza. Moreover, the combination of R. apiculata and E. agallocha in 1994, mostly within Sectors 2 and 5, is presently merged with $B$. gymnorrhiza. This shows the emerging growth of B. gymnorrhiza, with an increase in mean height from 1.95 to $5.8 \mathrm{~m}$, and dynamic shifts in young/adult vegetation occurring in only $10 \mathrm{yr}$ (Tables 1 $\& 2)$. Though much of the area containing $R$. apiculata in Sectors 1 and 2 


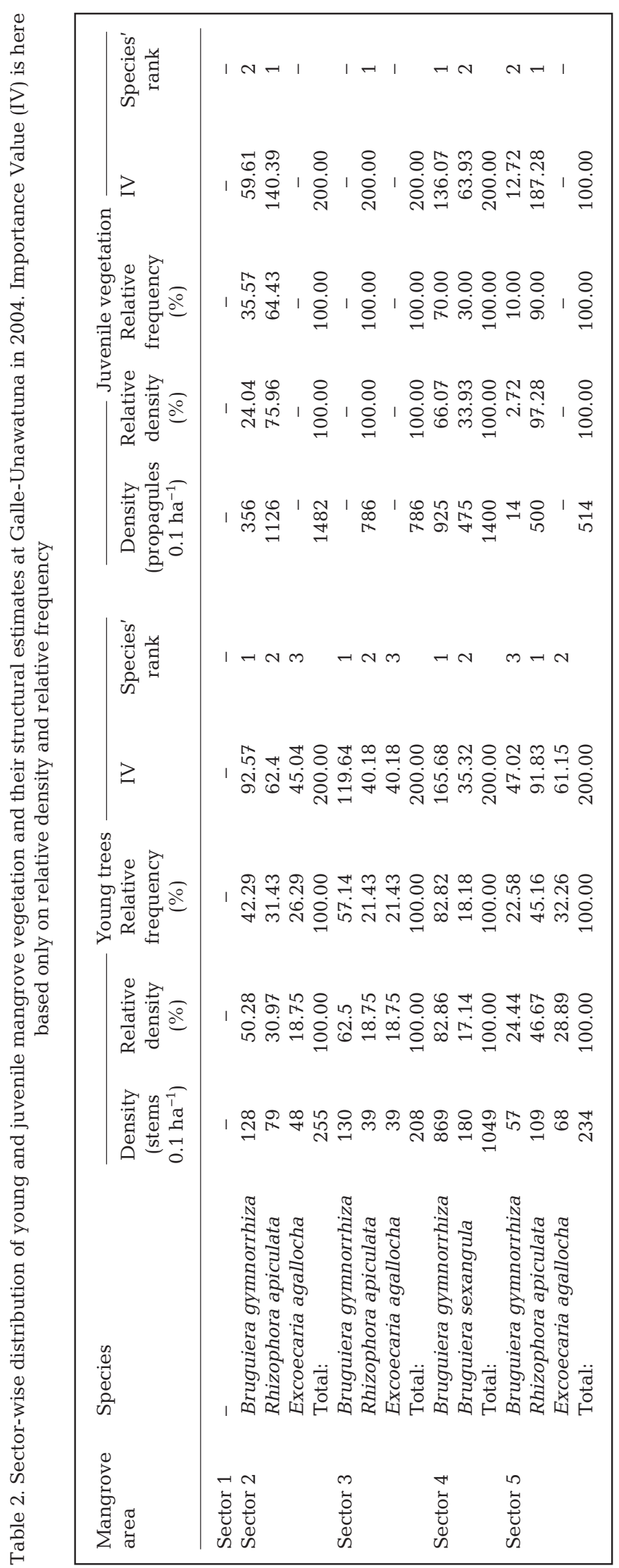

in 1994 is now co-dominated by E. agallocha, the former species is still omnipresent (constituting $28 \%$ of the total forest) followed by E. agallocha $(18 \%)$ and B. gymnorrhiza (14\%) (Table 4). The interchanging dominance of $R$. apiculata and $E$. agallocha was also observed over the previous decades (1956 to 2004) (Fig. 3). There has also been a steady decrease in Cocos nucifera following invasion by mangroves (Table 4).

\section{Species-environment relationship}

In the CCA (Fig. 4), ordination axes included environmental parameters to explain the variance in adult and young mangrove species data. The recorded values (range, mean $\pm \mathrm{SD}$ ) for each environmental parameter were as follows: salinity 2.7 to $15.3 \%$ o $(7.2 \pm 3.1)$, temperature 26.9 to $36.7^{\circ} \mathrm{C}(31.4 \pm 2.5)$, relative humidity 78 to $89 \%$ (85 \pm 2.8$)$, light intensity 132 to 41800 lux (7623 \pm $11869)$, and percentage land 7.5 to $100 \%$ (53.3 \pm 27.9). Axis 1 (eigenvalue: 0.04) explained up to $52 \%$ of the variance between species and the environmental parameters tested (roottransformed data), whereas Axis 2 (eigenvalue: 0.02 ) explained $22 \%$ (Fig. 4 ). The only variable associated with the positive side of Axes 1 and 2 was salinity influencing the distribution of Rhizophora apiculata $(\mathrm{p}=0.05, F$-ratio $=2.39)$, while the others did not have any significant role $(p>0.3)$ in explaining the variance in species composition.

\section{DISCUSSION}

\section{Factors affecting mangrove distribution}

The loss and expansion of mangroves between 1956 and 1994 in Galle-Unawatuna have been linked to human activities, such as coconut plantation and land reclamation (Dahdouh-Guebas et al. 2000, 2005a). Dahdouh-Guebas et al. (2000) also concluded that the mangroves here have undergone major dynamic shifts due to both direct (e.g. forest destruction) and indirect (e.g. physical infrastructure developments) anthropogenic events. During the process of transformation, some species have lost ground to other species and vice versa. This pattern of mangrove distribution is described as a 'moving mosaic'. In Galle-Unawatuna, the forest is also 


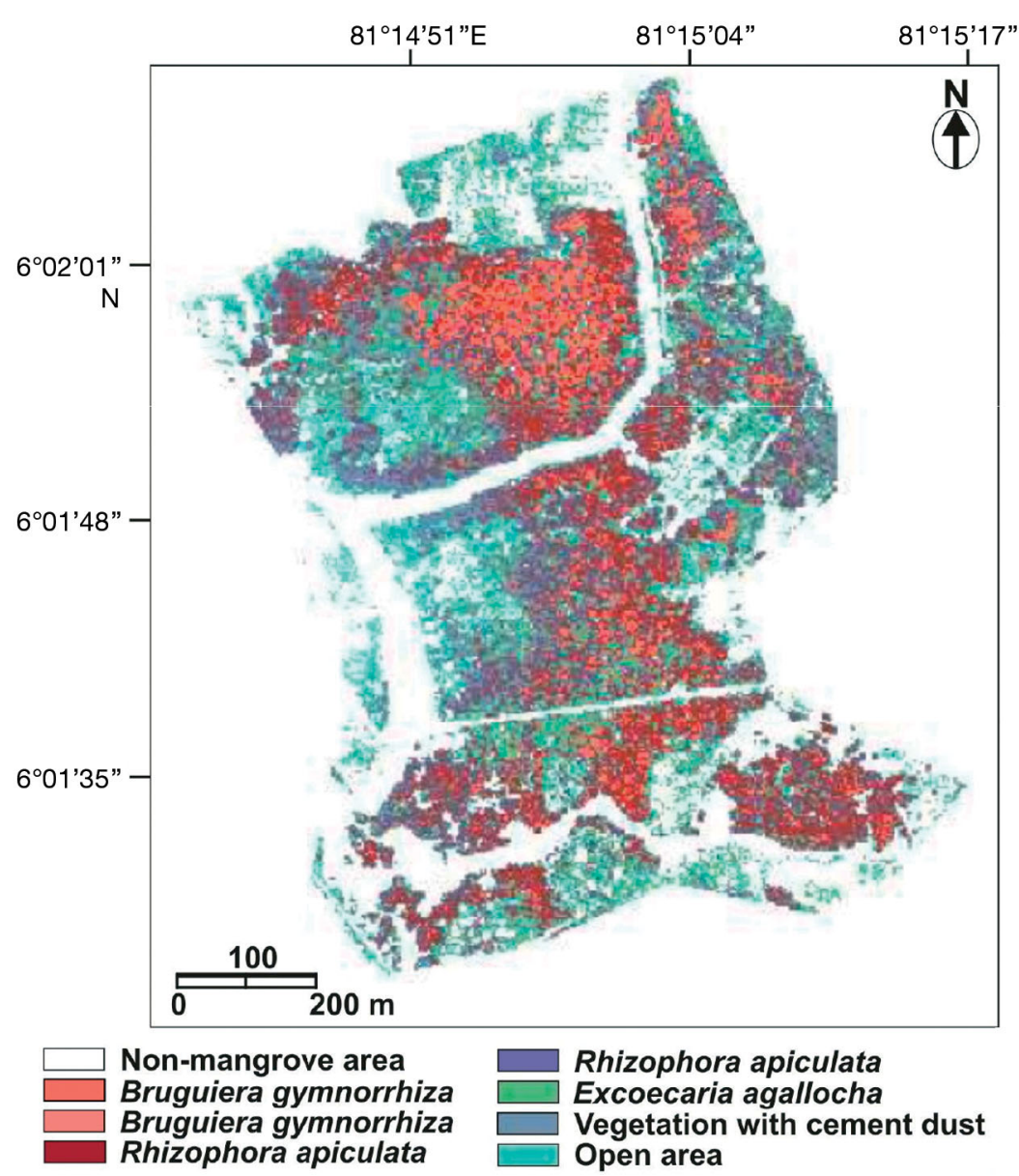

Fig. 2. Classified map of the Galle-Unawatuna mangroves based on pan-sharpened IKONOS satellite imagery (20 February 2004). Two classes each of Bruguiera and Rhizophora with a different spectral signature were detected on the image (and are shown as such here), but without marked differences in the field

\section{Mangrove classification and area statistics}

Although higher resolution may complicate the process of image classification, it is still advantageous for species-level identification and mapping (Satyanarayana et al. 2011). In the present study, the accuracy of our supervised classification was only $62.5 \%$ (Fig. 2), owing to the similar leaf reflectance of Rhizophora apiculata and Bruguiera gymnorrhiza. We also recall the difficulties arising from VHR imagery, as single trees tend not to be represented by one but by hundreds of pixels denoting different sections of the canopy (DahdouhGuebas et al. 2005a). On the other hand, for mapping of coastal habitats such as coral reefs, seagrasses and mangrove/non-mangrove areas, 60 to $80 \%$ accuracy is reasonable (Mumby et al. 1999).

However, the disparities in area statistics between supervised classification (Fig. 2) and the digitized vegetation map (Fig. 3) are understandable since the remote sensing data only represent canopy (see also DahdouhGuebas et al. 2004). Even though some species are densely populated on the ground, for example Excoecaria agallocha (mean height: $6.1 \mathrm{~m}$ ) in

characterized by an irregular topography created by the mangrove mud lobster (see Dahdouh-Guebas et al. 2000, 2011). In the present study, the loss of mangrove cover (4.1 ha) between 1994 and 2004 is largely due to fuelwood collection (Mulder 2005). Sector 2, which has a low structural complexity, has also exhibited major changes between 1974 and 1994, with explosive dispersal of Excoecaria agallocha (Dahdouh-Guebas et al. 2000).

Since most of the environmental parameters tested in this study vary daily with weather conditions (and daily tidal inundation is absent), our shortterm (about $2 \mathrm{mo}$ ) observations were not able to reveal their impact on local mangrove distribution, except salinity for Rhizophora apiculata. Similar observations were made by Dahdouh-Guebas et al. (2002) in their ordination analysis of disturbed/ undisturbed mangrove forests in Kenya and Sri Lanka.
Sector 2, they are overshadowed by tall neighboring trees such as Rhizophora apiculata (mean height: $8.5 \mathrm{~m})$. Therefore, the area covered by $R$. apiculata in the supervised classification $(42 \%)$ is overestimated in comparison with the vegetation map $(28 \%)$; and similarly, E. agallocha was underestimated (only $18 \%$ instead of $48 \%$ contribution together with Bruguiera gymnorrhiza and R. apiculata). The exclusive abundance of Bruguiera spp. (mean height: $5.8 \mathrm{~m})$ was also underestimated $(9 \%)$ in the supervised classification, due to the similar leaf reflectance of $R$. apiculata, which was already overestimated.

It must be noted that the area statistics derived from supervised classification can vary in their accuracy. Despite the ability of IKONOS images to provide higher classification accuracies for mangroves (Table 5), the homogeneous and/or heterogeneous criterion of the forest is still important for achieving good results (Evans et al. 2002, Wang et al. 2004a). 
Table 3. Error matrix based on the (2004) supervised classification of Galle-Unawatuna mangroves and ground-truth data

\begin{tabular}{|c|c|c|c|c|c|c|c|c|}
\hline \multirow{2}{*}{$\begin{array}{l}\text { Classification } \\
\text { data }\end{array}$} & \multirow[b]{2}{*}{$\begin{array}{c}\text { Bruguiera } \\
\text { gymnorrhiza }\end{array}$} & \multirow[b]{2}{*}{$\begin{array}{c}\text { Excoecaria } \\
\text { agallocha }\end{array}$} & \multicolumn{4}{|c|}{ Reference data } & \multirow{2}{*}{$\begin{array}{c}\text { User's } \\
\text { accuracy } \\
(\%)\end{array}$} & \multirow{2}{*}{$\begin{array}{c}\text { Errors of } \\
\text { commission } \\
(\%)\end{array}$} \\
\hline & & & $\begin{array}{c}\text { Rhizophora } \\
\text { apiculata }\end{array}$ & $\begin{array}{c}\text { Vegetation } \\
\text { with cement } \\
\text { dust }\end{array}$ & $\begin{array}{l}\text { Open } \\
\text { area }\end{array}$ & $\begin{array}{l}\text { Row } \\
\text { total }\end{array}$ & & \\
\hline Bruguiera gymnorrhiza & 15.60 & 6.80 & 16.25 & 0 & 0 & 38.65 & 40.36 & 59.64 \\
\hline Excoecaria agallocha & 6.40 & 19.10 & 8.10 & 0 & 0 & 33.60 & 56.84 & 43.16 \\
\hline Rhizophora apiculata & 2.80 & 6.25 & 45.10 & 0 & 0 & 54.15 & 83.29 & 16.71 \\
\hline Vegetation with cement dust & 9.10 & 10.35 & 30.50 & 30.50 & 0 & 49.95 & 61.06 & 38.94 \\
\hline Open area & 0 & 0 & 0 & 0 & $\mathbf{0}$ & 0 & 0 & 0 \\
\hline Column total & 33.90 & 42.50 & 99.95 & 0 & 0 & 176.35 & & \\
\hline Producer's accuracy (\%) & 46.02 & 44.94 & 45.12 & 30.50 & 0 & & & \\
\hline Errors of omission $(\%)$ & 53.98 & 55.06 & 54.88 & 69.50 & 0 & & & \\
\hline Overall accuracy (\%) & 62.55 & & & & & & & \\
\hline Kappa coefficient & 0.37 & & & & & & & \\
\hline Tau coefficient & 0.52 & & & & & & & \\
\hline
\end{tabular}

Perhaps image-processing techniques (with reference to IKONOS), such as integrated pixel- and object-based classification (Wang et al. 2004a) and inclusion of spatial texture as extra band (Wang et al. 2004b), might be useful for improving the classification accuracy of heterogeneous mangrove stands similar to Galle-Unawatuna.

\section{Testing mangrove predictions}

The assessment of mangroves through studying the spatio-temporal dynamics of land-use and cover patterns in the coastal zone is promising (DahdouhGuebas et al. 2004, Hernández-Cornejo et al. 2005). Although there is an enormous potential for integration of transdisciplinary data (Dahdouh-Guebas \& Koedam 2008), the integration of data on vegetation structure

Table 4. Area (ha) covered by the canopy mangrove vegetation classes in Galle-Unawatuna between 1956 and 1994 (adapted from Dahdouh-Guebas et al. 2000) and 2004 (present study)

\begin{tabular}{|lcccc|}
\hline Vegetation class & 1956 & 1974 & 1994 & 2004 \\
\hline Rhizophora apiculata & 21.7 & 20.0 & 20.3 & 13.9 \\
Excoecaria agallocha & 7.8 & 5.0 & 18.4 & 8.7 \\
Bruguiera gymnorrhiza & - & - & - & 7.1 \\
E. agallocha + Bruguiera spp. & 11.7 & 9.4 & 6.3 & - \\
E. agallocha + Rhizophora spp. & 6.7 & 15.1 & 8.6 & 10.4 \\
R. apiculata + B. gymnorrhiza & - & - & - & 1.0 \\
E. agallocha + R. apiculata + B. gymnorrhiza & - & - & - & 5.2 \\
Mangrove vegetation with cement dust & - & - & $-{ }^{\text {a }}$ & 3.2 \\
Total mangrove cover & $\mathbf{4 7 . 9}$ & $\mathbf{4 9 . 5}$ & $\mathbf{5 3 . 6}$ & $\mathbf{4 9 . 5}$ \\
Cocos nucifera & 25.1 & 19.4 & 12.1 & 2.3 \\
Water & 11.8 & 11.3 & 15.4 & 14.9 \\
aAlready present in 1994, but not classified as such & & & \\
\hline
\end{tabular}

dynamics from different moments in time has become almost entirely dependent on remote sensing.

The present study also discovered persisting mangroves dominated by Excoecaria agallocha and Rhizophora apiculata as adult vegetation (symbols 1 and 2 in Fig. 3), and Bruguiera gymnorrhiza as young vegetation (symbols 3 and 4 in Fig. 3) in Sectors 2 and 3, which were comparable in 1994 and 2004. Prediction 1 in the Introduction predicted the transition of an E. agallocha forest into a B. gymnorrhiza-dominated one or at least their co-dominance in Sectors 1 and 2. However, the present results show that B. gymnorrhiza is still young in Sector 2 (symbol 5 in Fig. 3), and suggest that the gap of 10 yr (in contrast to the 18 to $20 \mathrm{yr}$ intervals used by DahdouhGuebas et al. 2000) is not adequate to witness adult tree turnover here. Although confirming in part the earlier prediction for $R$. apiculata (with fewer numbers of Bruguiera spp., symbol 6 in Fig. 3) in Sector 3 (prediction 2 in the Introduction), the present study also revealed the abundance of $B$. gymnorrhiza as young and juvenile vegetation here. In general, the growth and survival of young trees/juveniles are dependent upon several environmental and anthropogenic factors that require continuous monitoring (Cannicci et al. 2008, Krauss et al. 2008). Though $R$. apiculata was abundant as juvenile vegetation in 1994 (symbols $(7$ and 8 in Fig. 3), only B. gymnorrhiza has survived and reached the young vegetation stage in 2004. This is indicative of the death of Rhizophora propagules before they reach 

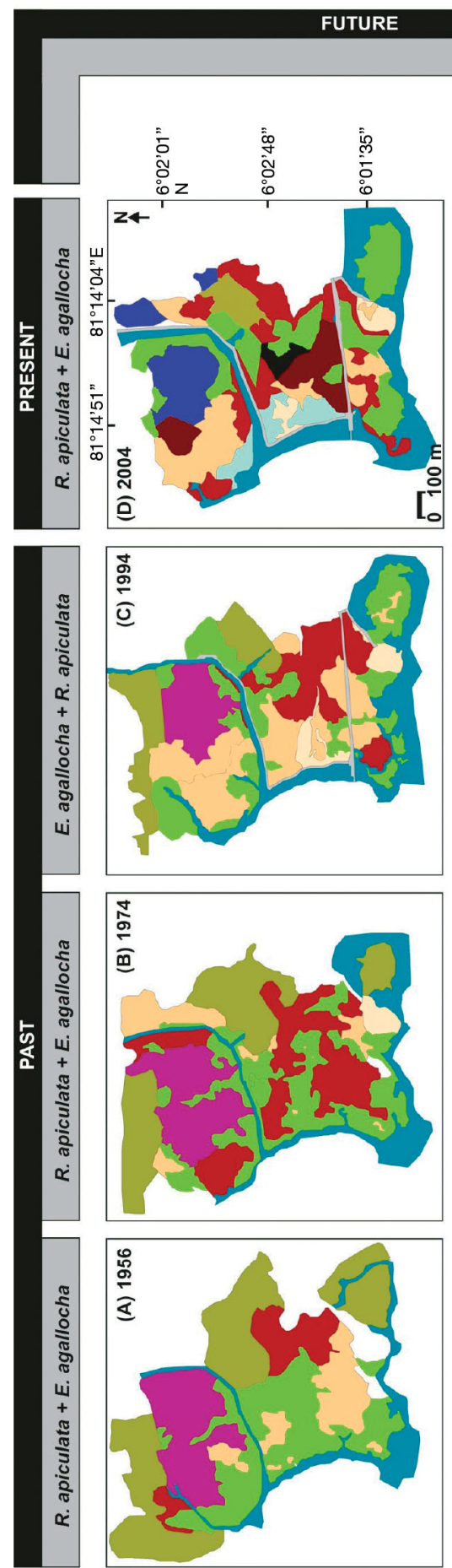

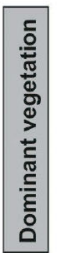

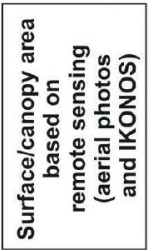

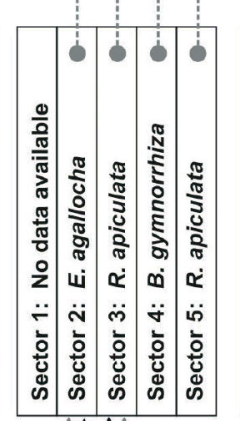
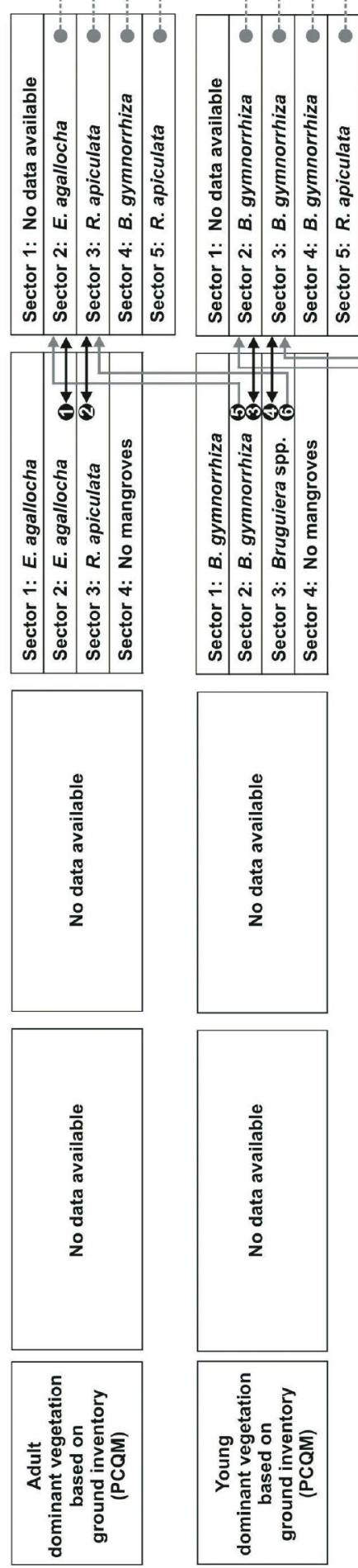
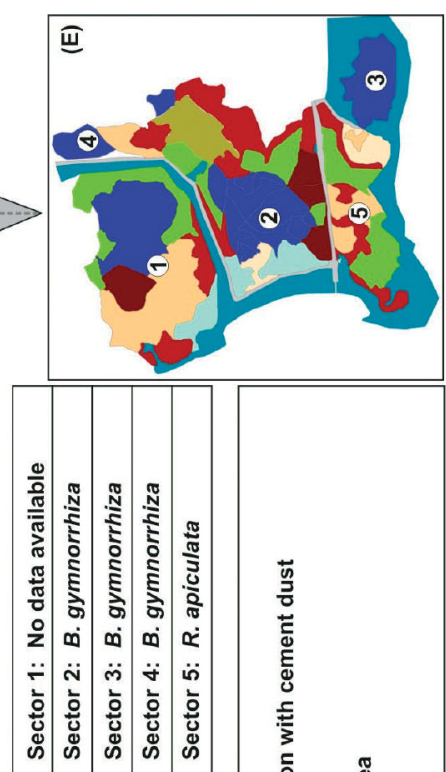
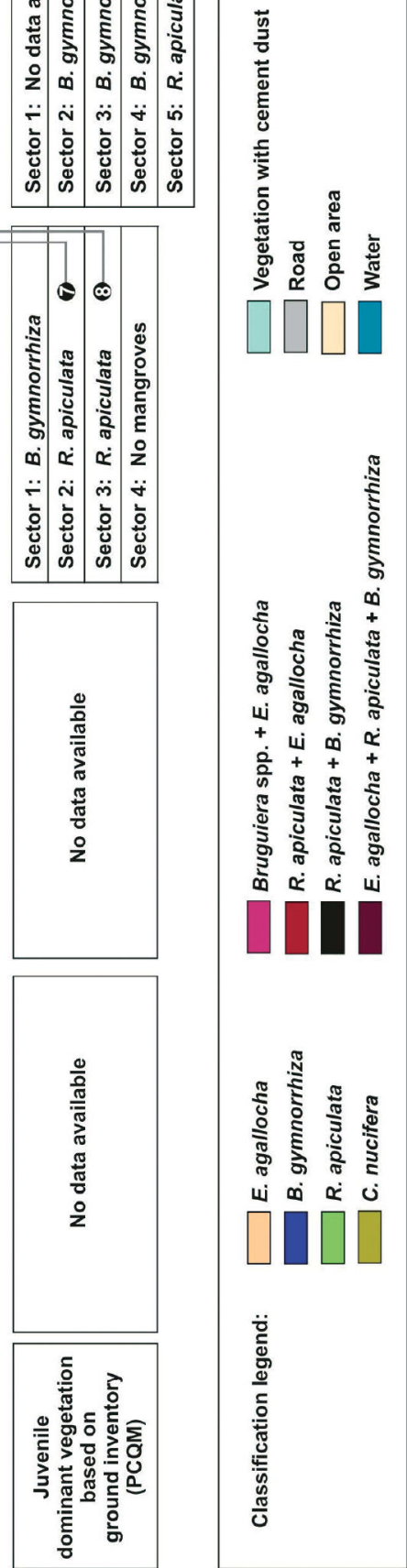

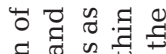

음

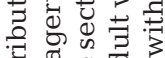

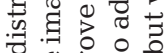

ชิ

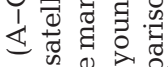

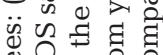

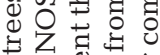

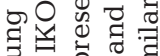

궁 융 잉

त वิ

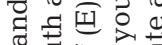

\pm 핑ㅇㅇ

검웜

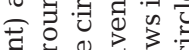

वै.

व व

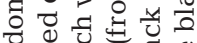

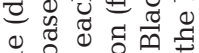

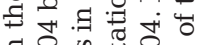

둥원

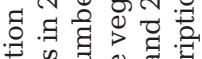

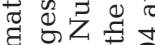

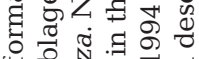

द्व 궘

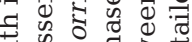

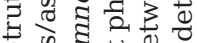

它.

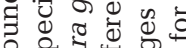

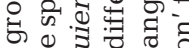

范

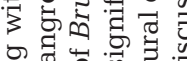

웜 त्वि

व

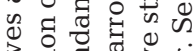

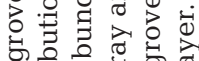

혈 융 क्ष

वี :

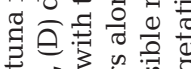

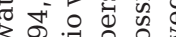

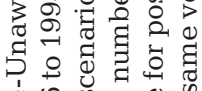

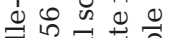

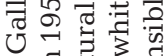

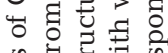

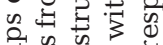

ฮี

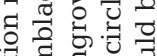

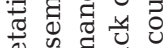

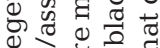

$\rightarrow$ को

웡ㄹㄹ 的

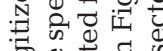

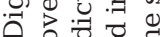

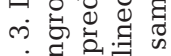

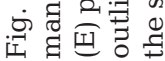


the young tree stage, resulting in part from propagule predation (Dahdouh-Guebas et al. 2011). Although the young B. gymnorrhiza trees have not yet passed the stage of surviving unfavorable environmental conditions, this species may supersede $E$.

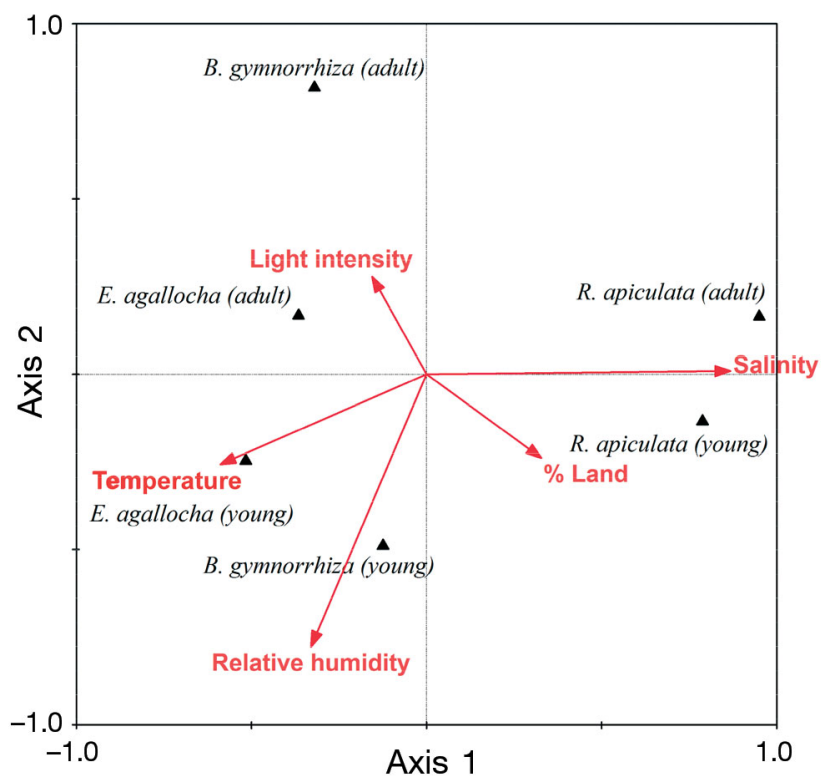

Fig. 4. Canonical correspondence analysis showing the biplot of the species-environment relationship for mangroves (B: Bruguiera; E: Excoecaria; R: Rhizophora) (data collected from 62 sample points was used). The percentages of variance of the species-environment relationship on Axes 1 and 2 are $52 \%$ and $22 \%$, respectively agallocha in both Sectors 1 and 2. The transition to a B. gymnorrhiza-dominated patch is also a possibility in Sector 3. Sectors 4 and 5 are already dominated by $B$. gymnorrhiza and $R$. apiculata respectively, and this trend may continue with no major transitions in the near future (Fig. 3). Viewing the present dynamic shifts and sheer dominance as young vegetation by B. gymnorrhiza in most sectors (Table 2, Fig. 3), it is still possible to conclude in a general way that the mangroves are dominated by this species (prediction 3 in the Introduction), which validates the predictions made 10 yr ago.

In the past, major portions of the mangroves in Galle-Unawatuna became dominated by Excoecaria agallocha (Dahdouh-Guebas et al. 2000). Ecologically, the newly evidenced and newly predicted transition towards Bruguiera-dominated mangroves is better for a 'mangrove' forest, since B. gymnorrhiza and other representatives of the family Rhizophoraceae are considered as true mangroves, valuable and highly functional (Dahdouh-Guebas et al. 2005a,b, Walters et al. 2008). The endurance of Bruguiera might be due to the mid-intertidal areas that it colonizes (Krauss \& Allen 2003), with poor marine and freshwater exchange after dam construction. Also, E. agallocha is a disturbance-resistant species (Tomlinson 1986), and indicative of terrestrialization, particularly in Sri Lanka (Dahdouh-Guebas et al. 2000, 2005a). There also exists a strong correlation between the number of crab and mud lobster

Table 5. Studies using IKONOS data for mangrove species-level classification/interpretation. MLC: maximum likelihood classification; MSS: multispectral sensor image; PAN: panchromatic image; NN: nearest neighborhood; MLCNN: integrated MLC and NN; OBC: object-based classification; LAI: leaf area index

\begin{tabular}{|lccc|}
\hline Study area and mangroves mapped & Techniques used & $\begin{array}{c}\text { Classification } \\
\text { accuracy (\%) }\end{array}$ & Source \\
\hline Punta Geleta (Panama) & & & \\
Avicennia germinans & MLC (MSS + PAN) & 88.9 & Wang et al. (2004a) \\
Laguncularia racemosa & NN (MSS + PAN) & 80.4 & Wang et al. (2004b) \\
Rhizophora mangle & MLCNN (MSS + PAN) & 75.3 & \\
Avicennia germinans & MLC (MSS) & 75.5 & Dahdouh-Guebas et al. (2005b) \\
Laguncularia racemosa & MLC (MSS + PAN) & 73 & \\
Rhizophora mangle & OBC (MSS + PAN + texture) & & \\
Pambala (Sri Lanka) & & & \\
Avicennia officinalis & Visual & & \\
Bruguiera gymnorrhiza & interpretation & & \\
Excoecaria agallocha & & & \\
Lumnitzera racemosa & & & \\
Rhizophora apiculata & & & \\
Rhizophora mucronata & & & \\
Agua Brava Lagoon (Mexican Pacific) & Aggregation of & & \\
Lumnitzera racemosa & LAI values & & \\
Rhizophora mangle & & & \\
\hline
\end{tabular}


burrows and the percentage land, as well as a strong interaction with propagule predation (Cannicci et al. 2008, Dahdouh-Guebas et al. 2011), which may further shape the vegetation structure and the dominance of the forest. In addition, there is a newly constructed highway (Matara-Colombo highway) behind the mangroves for which an access road from Galle (running across some freshwater inlets on the northern boundary) is under construction. This is also presumed to affect the hydrology of the mangrove waterways and ultimately the expected future trends of change.

\section{CONCLUSIONS AND RECOMMENDATIONS}

Validation of earlier predictions is a challenging but significant contribution to ecological research. Here we recall that Dahdouh-Guebas et al. (2000) predicted the transition of an Excoecaria agallocha forest into a Bruguiera gymnorrhiza-dominated one or at least their co-dominance in Sectors 1 and 2; continued dominance of Rhizophora apiculata in Sector $3 ;$ and in the future, the possibility of Bruguieradominated forest at Galle-Unawatuna. The present study has validated most of these forecasts and found that both E. agallocha and $R$. apiculata continue to be dominant in Sectors 2 and 3, although the replacement with adult B. gymnorrhiza (in Sector 2) has not yet occurred, probably due to the small time interval between the 2 investigations. The emerging growth of B. gymnorrhiza along with its dynamic shifts in young/adult vegetation does, however, support the earlier forecast that a major portion of this mangrove forest will become dominated by Bruguiera spp. in the near future. This makes our Galle-Unawatuna study site probably the world's most dynamic mangrove forest in terms of ground species (and with time ever more canopy species) turnover, displaying a new mosaic every 10 to $20 \mathrm{yr}$.

Since the mangroves at Galle-Unawatuna are surrounded by rural and urban settlements, many people depend on their resources, especially in terms of fishing and wood supply. Considering the influence of both natural and human-influenced biotic and abiotic factors on mangrove species distribution, growth and survival, the formulated predictions of future vegetation structure and observed vegetation dynamics may alter the course of development. According to Dahdouh-Guebas et al. $(2000,2005 a)$ and Mulder (2005), the 3 major physical infrastructure developments, i.e. the cement factory, dam and road, have started showing their negative impacts in the Galle-
Unawatuna area, beginning with water quality deterioration, and leading to dynamic changes in mangrove vegetation and impacts on biological productivity. Effects of hydrological changes (e.g. freshwater diversion, reduced tidal water exchange, accumulation of domestic/industrial sewage in mangrove waterways) on mangrove species distribution have also been reported elsewhere (e.g. Benfield et al. 2005, Mohamed et al. 2009, Bartolini et al. 2011, Cunha-Lignon et al. 2011). In this case, periodic opening of the dam gate is advisable to allow the ecological and economic benefits of this ecosystem to continue with minimal long-term effects. The dominance of Rhizophora apiculata and Excoecaria agallocha has changed over the decades (1956 to 1974 to 1994 to 2004), and the spatial distribution of mixed and monospecific mangrove stands could be linked to the 'moving mosaic' nature of these patches characteristically seen in this area.

Although several aspects of mangrove ecology, function and management are often discussed in the scientific literature, studies validating the ecosystem changes on a long-term basis are still limited. Therefore we also recommend that similar investigations be carried out in other mangrove areas for their efficient monitoring and management. The evident next step in our research approach is the use of individual-based modeling such as KiWi (e.g. Berger \& Hildenbrandt 2000, Berger et al. 2004, 2006, 2008) to both hindcast and forecast forest development while having at hand the very high resolution, long-term ground-truth data to validate the models.

Acknowledgements. B.S. is supported by the Belgian National Science Foundation (FNRS). Special thanks are due to Y. L. M. Vijedasa, S. Mulder, and several others for their kind support extended during the fieldwork. The work leading to these results has received funding from the European Community's Seventh Framework Program under grant agreement no. FP7-247514. Authors are very grateful to the 3 anonymous referees for their objective criticism and invaluable suggestions.

\section{LITERATURE CITED}

Alongi DM (2008) Mangrove forests: Resilience, protection from tsunamis, and responses to global climate change. Estuar Coast Shelf Sci 76:1-13

Bartolini F, Cimò F, Fusi M, Dahdouh-Guebas F, Lopes GP, Cannicci S (2011) The effect of sewage discharge on the ecosystem engineering activities of two East African fiddler crab species: consequences for mangrove ecosystem functioning. Mar Environ Res 71:53-61

Benfield SL, Guzman HM, Mair JM (2005) Temporal mangrove dynamics in relation to coastal development in Pacific Panama. J Environ Manag 76:263-276

Berger U, Hildenbrandt H (2000) A new approach to spa- 
tially explicit modelling of forest dynamics: spacing, ageing and neighbourhood competition of mangrove trees. Ecol Model 132:287-302

Berger U, Hildenbrandt H, Grimm V (2004) Age-related decline in forest production: modelling the effects of growth limitation, neighbourhood competition and selfthinning. J Ecol 92:846-853

- Berger U, Adams M, Grimm V, Hildenbrandt H (2006) Modelling secondary succession of neotropical mangroves: causes and consequences of growth reduction in pioneer species. Perspect Plant Ecol Evol Syst 7:243-252

Berger U, Rivera-Monroy VH, Doyle TW, Dahdouh-Guebas $\mathrm{F}$ and others (2008) Advances and limitations of individual-based models to analyze and predict dynamics of mangrove forests: a review. Aquat Bot 89:260-274

Bosire JO, Kairo JG, Kazungu J, Koedam N, Dahdouh-Guebas F (2005) Predation on propagules regulates regeneration in a high-density reforested mangrove plantation. Mar Ecol Prog Ser 299:149-155

> Bosire JO, Dahdouh-Guebas F, Walton M, Crona BI and others (2008) Functionality of restored mangroves: a review. Aquat Bot 89:251-259

> Cannicci S, Burrows D, Fratini S, Smith TJ III, Offenberg J, Dahdouh-Guebas F (2008) Faunal impact on vegetation structure and ecosystem function in mangrove forests: a review. Aquat Bot 89:186-200

Cintron G, Schaeffer Novelli Y (1984) Methods for studying mangrove structure. In: Samuel CS, Jane GS (eds) The mangrove ecosystem: research methods. UNESCO publication, Paris, p 91-113

Congalton RG (1991) A review of assessing the accuracy of classifications of remotely sensed data. Remote Sens Environ 37:35-46

Cunha-Lignon M, Kampel M, Menghini RP, SchaefferNovelli Y, Cintrón G, Dahdouh-Guebas F (2011) Mangrove forests submitted to depositional processes and salinity variation investigated using satellite images and vegetation structure surveys. J Coast Res Spec Issue 64: 344-348

> Dahdouh-Guebas F, Koedam N (2006a) Coastal vegetation and the Asian tsunami. Science 311:37-38

> Dahdouh-Guebas F, Koedam N (2006b) Empirical estimate of the reliability of the use of the Point-Centred Quarter Method (PCQM): solutions to ambiguous field situations and description of the PCQM+ protocol. For Ecol Manag 228:1-18

> Dahdouh-Guebas F, Koedam N (2008) Long-term retrospection on mangrove development using transdisciplinary approaches: a review. Aquat Bot 89:80-92

Dahdouh-Guebas F, Verheyden A, De Genst W, Hettiarachchi S, Koedam N (2000) Four decade vegetation dynamics in Sri Lankan mangroves as detected from sequential aerial photography: a case study in Galle. Bull Mar Sci 67:741-759

> Dahdouh-Guebas F, Kairo JG, Jayatissa LP, Cannicci S, Koedam N (2002) An ordination study to view vegetation structure dynamics in disturbed and undisturbed mangrove forests in Kenya and Sri Lanka. Plant Ecol 161: 123-135

> Dahdouh-Guebas F, Van Pottelbergh I, Kairo JG, Cannicci S, Koedam N (2004) Human-impacted mangroves in Gazi (Kenya): predicting future vegetation based on retrospective remote sensing, social surveys, and tree distribution. Mar Ecol Prog Ser 272:77-92

> Dahdouh-Guebas F, Hettiarachchi S, Sooriyarachchi S, Lo
Seen D, Batelaan O, Jayatissa LP, Koedam N (2005a) Transitions in ancient inland freshwater resource management in Sri Lanka affect biota and human populations in and around coastal lagoons. Curr Biol 15: 579-586

Dahdouh-Guebas F, Van Hiel E, Chan JCW, Jayatissa LP, Koedam N (2005b) Qualitative distinction of congeneric and introgressive mangrove species in mixed patchy forest assemblages using high spatial resolution remotely sensed imagery (IKONOS). Syst Biodivers 2:113-119

Dahdouh-Guebas F, Verheyden A, Kairo JG, Jayatissa LP, Koedam N (2006) Capacity building in tropical coastal resource monitoring in developing countries: a re-appreciation of the oldest remote sensing method. Int J Sustain Dev World Ecol 13:62-76

Dahdouh-Guebas F, Kairo JG, Bondt RD, Koedam N (2007) Pneumatophore height and density in relation to microtopography in the grey mangrove Avicennia marina. Belg J Bot 140:213-221

Dahdouh-Guebas F, Koedam N, Satyanarayana B, Cannicci S (2011) Human hydrographical changes interact with propagule predation behaviour in Sri Lankan mangrove forests. J Exp Mar Biol Ecol 399:188-200

Di Nitto D, Dahdouh-Guebas F, Kairo JG, Decleir H, Koedam N (2008) Digital terrain modelling to investigate the effects of sea level rise on mangrove propagule establishment. Mar Ecol Prog Ser 356:175-188

> Donato DC, Kauffman JB, Murdiyarso D, Kurnianto S, Stidham M, Kanninen M (2011) Mangroves among the most carbon-rich forests in the tropics. Nat Geosci 4:293-297

Duke NC, Meynecke JO, Dittmann S, Ellison AM and others (2007) A world without mangroves? Science 317:41-42

> Ellison AM (2008) Managing mangroves with benthic biodiversity in mind: moving beyond roving banditry. J Sea Res 59:2-15

Evans C, Jones R, Svalbe I, Berman M (2002) Segmenting multispectral Landsat TM images into field units. IEEE Trans Geosci Remote Sens 40:1054-1064

Feagin RA, Mukherjee N, Shanker K, Baird AH and others (2010) Shelter from the storm? Use and misuse of coastal vegetation bioshields for managing natural disasters. Conserv Lett 3:1-11

Gilman EL, Ellison J, Duke NC, Field C (2008) Threats to mangroves from climate change and adaptation options: a review. Aquat Bot 89:237-250

> Giri C, Pengra B, Zhu Z, Singh A, Tieszen LL (2007) Monitoring mangrove forest dynamics of the Sundarbans in Bangladesh and India using multi-temporal satellite data from 1973 to 2000. Estuar Coast Shelf Sci 73:91-100

Giri C, Zhu Z, Tieszen LL, Singh A, Gillette S, Kelmelis JA (2008) Mangrove forest distributions and dynamics (1975-2005) of the tsunami-affected region of Asia. J Biogeogr 35:519-528

Giri C, Ochieng E, Tieszen LL, Zhu Z and others (2011) Status and distribution of mangrove forests of the world using earth observation satellite data. Glob Ecol Biogeogr 20:154-159

Hernández-Cornejo R, Koedam N, Ruiz Luna A, Troell M, Dahdouh-Guebas F (2005) Remote sensing and ethnobotanical assessment of the mangrove forest changes in the Navachiste-San Ignacio-Macapule lagoon complex, Sinaloa, Mexico. Ecol Soc 10:16

Holdridge L, Grenke WC, Hatheway WH, Liang T, Tosi JA (1971) Forest environment in tropical life zones. Pergamon Press, New York, NY 
Jayatissa LP, Dahdouh-Guebas F, Koedam N (2002) A review of the floral composition and distribution of mangroves in Sri Lanka. Bot J Linn Soc 138:29-43

Kairo JG, Dahdouh-Guebas F, Bosire J, Koedam N (2001) Restoration and management of mangrove systems - a lesson for and from the East African region. S Afr J Bot 67:383-389

Kairo JG, Dahdouh-Guebas F, Gwada PO (2002) Regeneration status of mangrove forests in Mida creek, Kenya: a compromised or secured future? Ambio 31:562-568

Kovacs JM, Flores-Verdugo F, Wang J, Aspden LP (2004) Estimating leaf area index of a degraded mangrove forest using high spatial resolution satellite data. Aquat Bot 80:13-22

Kovacs JM, Wang J, Flores-Verdugo F (2005) Mapping mangrove leaf area index at the species level using IKONOS and LAI-2000 sensors for the Agua Brava Lagoon, Mexican Pacific. Estuar Coast Shelf Sci 62:377-384

Krauss KW, Allen JA (2003) Factors influencing the regeneration of the mangrove Bruguiera gymnorrhiza (L.) Lamk. on a tropical Pacific island. For Ecol Manag 176:49-60

Krauss KW, Lovelock CE, McKee KL, López-Hoffman L, Ewe SML, Sousa WP (2008) Environmental drivers in mangrove establishment and early development: a review. Aquat Bot 89:105-127

Massó i Alemán S, Bourgeois C, Appeltans W, Vanhoorne B and others (2010) The 'Mangrove Reference Database and Herbarium'. Plant Ecol Evol 143:225-232

Mohamed MOS, Neukermans G, Kairo JG, Dahdouh-Guebas F, Koedam N (2009) Mangrove forests in a peri-urban setting: the case of Mombasa (Kenya). Wetl Ecol Manag $17: 243-255$

Mulder S (2005) Local resource use and stakeholders' perceptions of the dynamics of mangrove degradation in Galle, Sri Lanka, with implications for conservation policy and research. MSc thesis, Vrije Universiteit Brussel

Mumby PJ, Green EP, Edwards AJ, Clark CD (1999) The cost-effectiveness of remote sensing for tropical coastal resources assessment and management. J Environ Manage 55:157-166

Mumby PJ, Edwards AJ, Arias-González JE, Lindeman KC and others (2004) Mangroves enhance the biomass of coral reef fish communities in the Caribbean. Nature 427:533-536

Nagelkerken I, Blaber SJM, Bouillon S, Green P and others (2008) The habitat function of mangroves for terrestrial and marine fauna: a review. Aquat Bot 89:155-185

Neukermans G, Dahdouh-Guebas F, Kairo JG, Koedam N (2008) Mangrove species and stand mapping in Gazi Bay (Kenya) using QuickBird satellite imagery. J Spat Sci 53:

Editorial responsibility: Just Cebrian,

Dauphin Island, Alabama, USA
75-86

Proisy C, Couteron P, Fromard F (2007) Predicting and mapping mangrove biomass from canopy grain analysis using Fourier-based textural ordination of IKONOS images. Remote Sens Environ 109:379-392

Quartel S, Kroon A, Augustinus PGEF, Santen PV, Tri NH (2007) Wave attenuation in coastal mangroves in the Red River Delta, Vietnam. J Asian Earth Sci 29:576-584

Ren H, Lu H, Shen W, Huang C, Guo Q, Li Z, Jian S (2009) Sonneratia apetala Buch. Ham in the mangrove ecosystems of China: an invasive species or restoration species? Ecol Eng 35:1243-1248

Sanford MP (2009) Valuing mangrove ecosystems as coastal protection in post-tsunami South Asia. Nat Areas J 29: 91-95

Satyanarayana B, Khairul Azwan M, Indra Farid I, MohdLokman H, Dahdouh-Guebas F (2011) Assessment of mangrove vegetation based on remote sensing and ground-truth measurements at Tumpat, Kelantan Delta, east coast of Peninsular Malaysia. Int J Remote Sens 32: 1635-1650

Souza Filho PWM, Farias Martins EdS, da Costa FR (2006) Using mangroves as a geological indicator of coastal changes in the Bragança macrotidal flat, Brazilian Amazon: a remote sensing data approach. Ocean Coast Manag 49:462-475

ter Braak CJF, Smilauer P (2002) CANOCO reference manual and CanoDRAW for Windows user's guide: software for canonical community ordination (version 4.5). Microcomputer Power, Ithaca, NY

Tomlinson PB (1986) The botany of mangroves. Cambridge University Press, New York, NY

- Valiela I, Bowen JL, York JK (2001) Mangrove forests: one of the world's threatened major tropical environments. Bioscience 51:807-815

> Verheyden A, Dahdouh-Guebas F, Thomaes K, De Genst W, Hettiarachchi S, Koedam N (2002) High resolution vegetation data for mangrove research as obtained from aerial photography. Environ Dev Sustain 4:113-133

> Walters BB, Rönnbäck P, Kovacs JM, Crona B and others (2008) Ethnobiology, socio-economics and management of mangrove forests: a review. Aquat Bot 89:220-236

> Wang L, Sousa WP, Gong P (2004a) Integration of objectbased and pixel-based classification for mapping mangroves with IKONOS imagery. Int J Remote Sens 25: 5655-5668

> Wang L, Sousa WP, Gong P, Biging GS (2004b) Comparison of IKONOS and QuickBird images for mapping mangrove species on the Caribbean coast of Panama. Remote Sens Environ 91:432-440

Submitted: August 11, 2010; Accepted: September 14, 2011 Proofs received from author(s): November 30, 2011 